\title{
Aluminum Infiltration into Molybdenum Silicide Preforms
}

\author{
Anup K. Bhattacharya, T. A. Bhaskaran, and Sheela K. Ramasesha \\ National Aerospace Laboratories, Bangalore 560017, India
}

\begin{abstract}
The presence of $\mathrm{Mo}_{5} \mathrm{Si}_{3}$ in $\mathrm{MoSi}_{2}$ preforms hinders the reactive infiltration of aluminum. To understand the role of $\mathrm{Mo}_{5} \mathrm{Si}_{3}$, the kinetics of aluminum infiltration into pure $\mathrm{Mo}_{5} \mathrm{Si}_{3}$ is studied. Irrespective of the initial composition $\left(\mathrm{MoSi}_{2}\right.$ or $\left.\mathrm{Mo}_{5} \mathrm{Si}_{3}\right)$ of the preform, the final product always contains $\mathrm{Mo}(\mathrm{Al}, \mathrm{Si})_{2}$. However, the aluminum content in the two cases is different: when the preform is $\mathrm{MoSi}_{2}$, the aluminum content is 14-18 at.\%, and, when the preform is $\mathrm{Mo}_{5} \mathrm{Si}_{3}$, the aluminum content is 25-27 at. \%. The activation energy for the reactive infiltration of aluminum into the $\mathrm{Mo}_{5} \mathrm{Si}_{3}$ preform is $\sim 26 \mathrm{~kJ} / \mathrm{mol}$.
\end{abstract}

\section{Introduction}

$\mathrm{R}$ DACIIVE MELT INFILTRATION (RMI) is a versatile method for preparing ceramic-metal composites. Here, a molten metal wets the surface and reacts with the preform while penetrating into it. This type of wetling-assisted infiltration, without the application of external pressure, provides near-net-shaped products with less residual porosity and has the potential to form a metal-ceramic composite with controlled composition and properties. Reactive infiltration of aluminum into $\mathrm{MoSi}_{2}$ is one such example.' Here aluminum reacts with $\mathrm{MoSi}_{2}$ to form a $\mathrm{Mo}(\mathrm{Al}, \mathrm{Si})_{2}$ and $\mathrm{Al}-\mathrm{Si}$ composite as follows:

$$
\mathrm{MoSi}_{2}+2 x \mathrm{Al} \rightarrow \mathrm{Mo}\left(\mathrm{Al}_{4} \mathrm{Si}_{1-. .}\right)_{2}+2 x \mathrm{Si}
$$

This chemical reaction enhances wetting and, hence, infiltration. A capillary rise/viscous flow mechanism and chemical reaction ${ }^{2-4}$ may explain the infiltration rate. For example, an activation energy of $8.4 \mathrm{~kJ} / \mathrm{mol}$ has been found for the infiltration of lead into a copper powder compact. ${ }^{3}$ This value is very close to the activation energies for viscous flow and self-diffusion of liquid lead. Where the infiltration process is governed by a chemical reaction, activation energy values are very large, as in the infiltration of aluminum into MoS $\mathrm{I}_{2}$, which is $\sim 30(0) \mathrm{kJ} / \mathrm{mol}$. $^{\prime}$

$\mathrm{MoSi}_{2}$ is a potential structural material for use in aggressive environments. It has been reported that the addition of aluminum and formation of $\mathrm{Mo}(\mathrm{Al}, \mathrm{Si})_{2}$ improves the mechanical and oxidation properties of $\mathrm{MoSi}_{2},{ }^{5,6}$ Infiltration may be one of the processes to obtain a composite of aluminum and $\mathrm{Mo}(\mathrm{Al}, \mathrm{Si})_{2}$. Irrespective of infiltration conditions, $14-18$ at.\% of aluminum has been found to react with $\mathrm{MoSi}_{2}$.' To absorb the byproduct silicon, a preform of a mixture of elemental molybdenum and $\mathrm{MoSi}_{2}$ is used, and the final composition after infifltution contains no free silicon. ${ }^{7}$

In an attempt to decrease the aluminum content in the final composite, a $\mathrm{MoSi}_{2}-\mathrm{Mo}$ mixture was hot-pressed at 150()$^{\circ} \mathrm{C}$ to obtain an $85 \%$ dense preform. After the preform was sintered, it was found to contain $\mathrm{MoSi}_{2}$ and $\mathrm{Mo}_{5} \mathrm{Si}_{3}$. The infiltration rate was not as high as that in pure MoSU. The presence of $\mathrm{Mo}_{5} \mathrm{Si}_{3}$

B. Derby-contibuting editor

Manuseript No. 188132. Received November 21, 2000; approved February 4, 2002 . impurities may have affected the rate of infiltration. To test this hypothesis, we conducted RMI into pure $\mathrm{MO}_{5} \mathrm{Si}_{3}$ preforms, and we present the results in this communication.

\section{Experimental Procedure}

$\mathrm{MoSi}_{2}(2.93 \mu \mathrm{m}$, Japan New Metals, Osaka, Japan) and 23.37 wi\% molybdenum (3.8 $\mu \mathrm{m}$, Aldrich Chemical Co., Milwaukee, WI) were mixed and hot-pressed at $1700^{\circ} \mathrm{C}$ and $22 \mathrm{MPa}$ pressure in an argon atmosphere to form $\mathrm{Mo}_{5} \mathrm{Si}_{3}$. The infiltration was conducted by placing a solid Al-Si $(12.2 \mathrm{wt} \%)$ alloy on top of the $\mathrm{MoSi}_{2}-\mathrm{Mo}$ compact. Infiltration was first conducted at $1200^{\circ} \mathrm{C}$ for $15 \mathrm{~min}$ and then increased to $1600^{\circ} \mathrm{C}$, where it was held for 10 min. After infiltration, the sample was cut and the cross section was polished with $1 \mu \mathrm{m}$ diamond paste to determine the microstructure and extent of infiltration,

To synthesize $\mathrm{Mo}_{5} \mathrm{Si}_{3}$ compacts, molybdenum and silicon (6 $\mu m$, Aldrich Chemical Co.) powders were mixed in stoichiometric proportion, and the mixture was hot-pressed in a graphite die at $1600^{\circ} \mathrm{C}$ and $16 \mathrm{MPa}$. An $80 \%$ dense $\mathrm{Mo}_{5} \mathrm{Si}_{3}$ was obtained, which then was cut in equal-sized (4.8 $\mathrm{mm} \mathrm{X} 3,5 \mathrm{~mm} X 3.5$ nun) rectangular bars. Infiltration was conducted by placing the solid $\mathrm{Al}-\mathrm{Si}$ pieces over the preform bars, inside a graphite crucible. The infiltration temperature was varied $1200^{\circ}-1500^{\circ} \mathrm{C}$, keeping the duration constant at $20 \mathrm{~min}$. For the other set of experiments, the duration of infiltration was 20-60 min, keeping the temperature constant at $1400^{\circ} \mathrm{C}$. Infiltrated samples were cul and each cross section was polished to study the infiltration process.

X-ray diffractometry (XRD; Model D/MAX 220) Uleima, Riguku, Tokyo, Japan) and scanning electron microscopy (SEM: Model 440, Leo Electron Microscopy, Ltd., Cambridge, U.K.) were used for characterization studies.

\section{HI. Results and Discussion}

The XRD pattern (litg. 1(a)) of a sintered MoSi, -I- Mo simmple shows the presence of $M \mathcal{O S S}_{\text {, }}$ and $\mathrm{Mo}_{5} S \mathrm{Sl}_{3}$. After infiltration with aluminum alloy (Fig. 1(b)), the sample contained only $\mathrm{Mo}(\mathrm{Al}, \mathrm{Si})_{2}$ and the aluminum alloy. In a $2.5 \mathrm{~mm}$ thick sample, infiltration was not complete, even though the infiltrition was first conducted at $12000^{\circ} \mathrm{C}$ for $15 \mathrm{~min}$, then held at $\left.16(0)\right)^{\circ} \mathrm{C}$ for $10 \mathrm{~min}$. In an $85 \%$ dense $\mathrm{MoSi}_{2}$ preform of the same thickness, the infiltration was

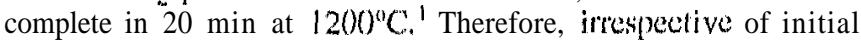
composition, the final product was always $\mathrm{Mo}(\mathrm{Al}, \mathrm{Si})_{2}$. However, the rate of infiltration depended on the composition of the preform. In this case, the rate may have decreased becituse of the presence of $\mathrm{M}_{\mathrm{C}_{5}} \mathrm{Si}_{3}$ in the initial preform.

The microstructure of the infiltrated $\mathrm{Mo}_{5} \mathrm{Si}_{3}$ at $14000^{\circ} \mathrm{C}$ for 20 min is shown in Fig. 2. The infiltrated zons, uninlilluted zone, and the interface zone between them are shown. The black region is aluminum alloy and the dark-gray region contains aluminum $(\cdots 74$ at.\%), molybdenum (-21 at. $\%)$, and silicon. The dark-gray phase is mainly present in the interface region. Light-gray hexagonal particles are $\mathrm{Mo}(\mathrm{Al}, \mathrm{Si})_{2}$. On average, $25-27$ at.\% of the aluminun is present in these $\mathrm{Mo}(\mathrm{Al}, \mathrm{Si})_{2}$ grains, whereas $14-18$ at.\% alumi. num is present in the $\mathrm{Mo}(\mathrm{A} I, \mathrm{Si})_{2}$ grains after the infiltration of the 


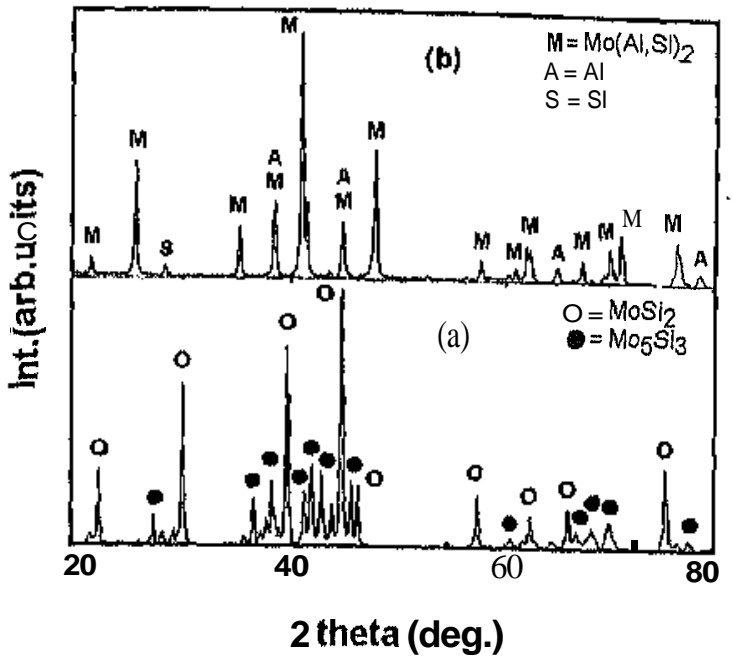

Fig. 1. XRD pralterll wl' sistewed MoSi; + Mo sample (a) before and (b) after aluminum iubiliration.

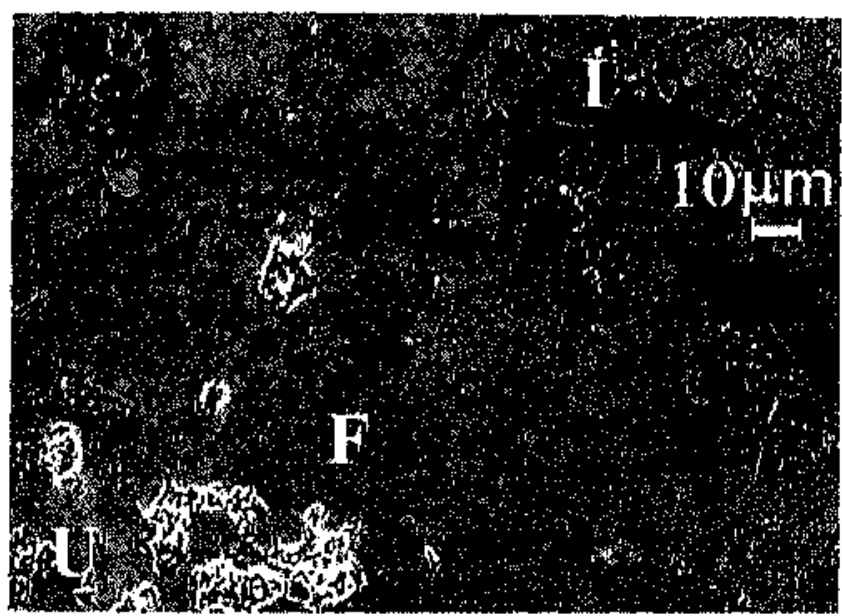

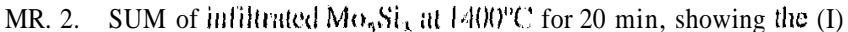

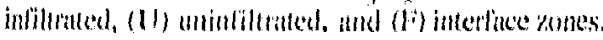

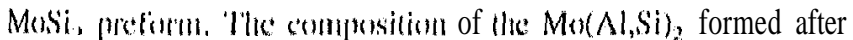
the infiltration depends on the chemicall composilion of the prefirin. W.

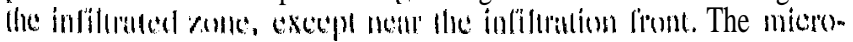
strueture of the inlilututed composite depends on the initial perform, When Ihe pretism is $\mathrm{Mu}_{3} \mathrm{Si}_{3}$, hexagonal grains occur

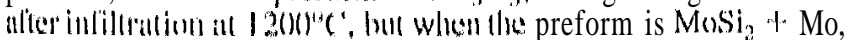

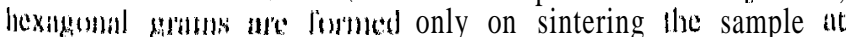

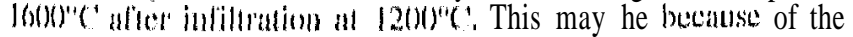

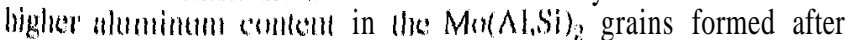

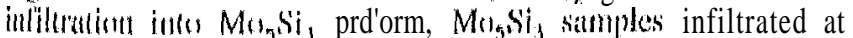

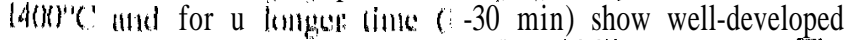
hexagonal crystillike structures of Mo(Al.Si), (Fig. 3), The chemical composilion of these struetures is the same as that of the lightumpray lexaguntil particless shown in lïg, 2.

$\mathrm{X}$-ray mapping ol'the inlilliraled $\mathrm{Mos}_{5} \mathrm{Si}_{1}$, sample is shown in Fig. 4. Molybuenum and aluminum are well clistributed and dense in

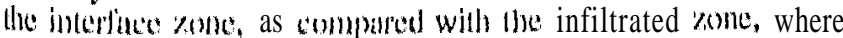
gluins are well keveloped. Molyblenum that is coming out after the reiction of aluminum with Mors Si, forms a different phase with iiluminum that is prestent mainly in the interfice region. Hence, in this region, iiluminum and molybdenum arc present over Ihe entire uteta, whereas, in the infillruted \%one, there are places where iiluminum and molybdenum do not coexist. Mo ${ }_{5} \mathrm{Si}_{3}$ reacls with aluminum as follows:

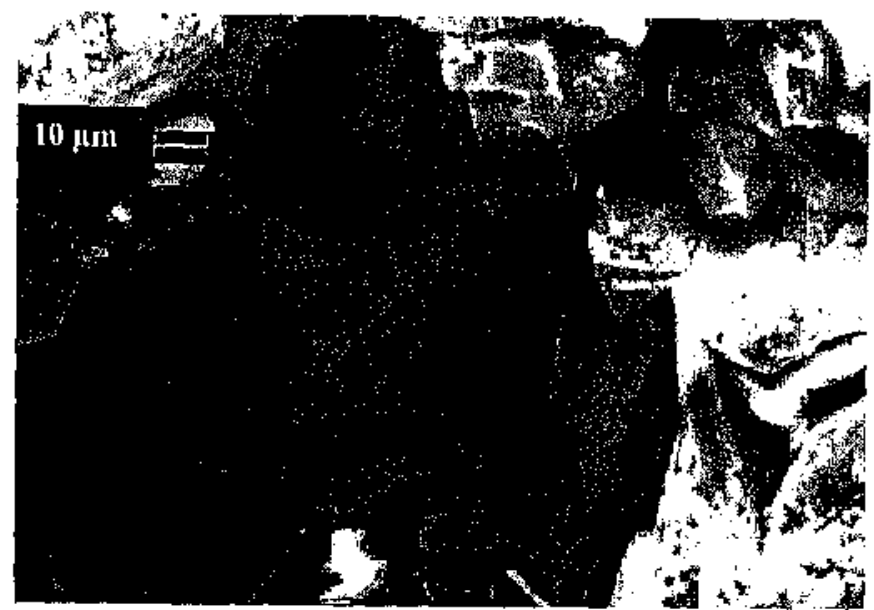

Fig. 3. SEM of the fractured surface of $\mathrm{Mo}_{5} \mathrm{Si}_{3}$ infiltrated at $1400^{\circ} \mathrm{C}$ for $30 \mathrm{~min}$. Well-developed hexagonal crystallike structures of $\mathrm{Mo}(\mathrm{Al}, \mathrm{Si})_{2}$ are shown.

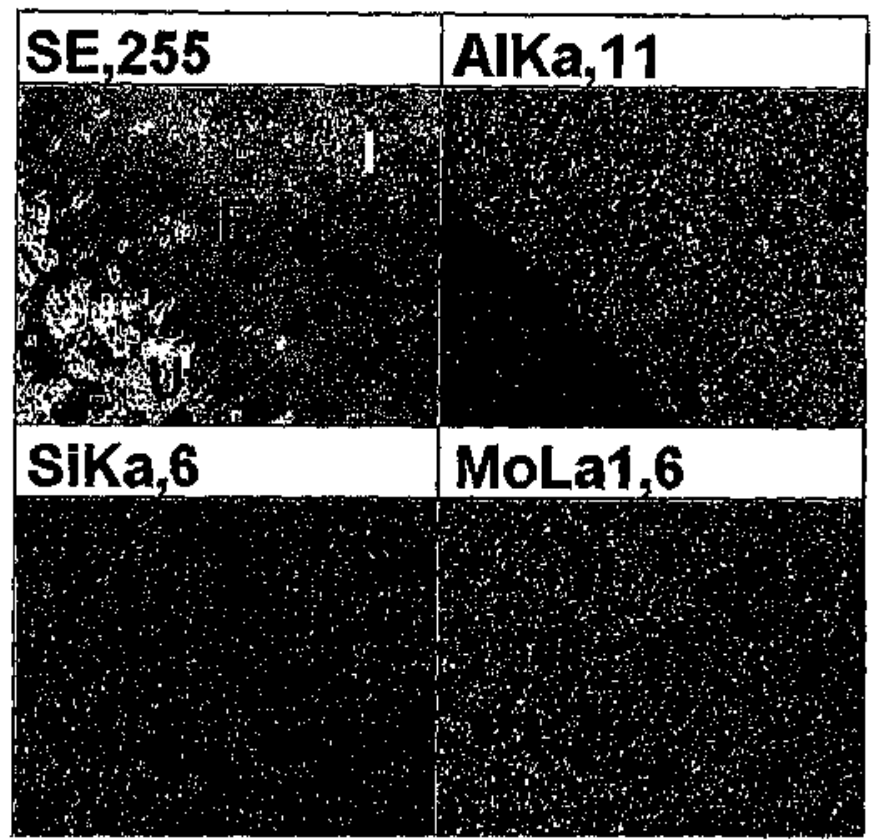

Tig. 4. X-ray mapping of infiltrited $\mathrm{Mog}_{9} \mathrm{Si}_{3}$ at $1400^{\circ} \mathrm{C}$ for $20 \mathrm{~min}$, showing the infiltration front (I) infiltated, (U) uninfiltrated, and (F) interfice zones).

The elemental molybdenum that is released after the reaction dilfises in a direction opposite to the infiltration direction. This molybdenum reacts with the aluminum to form a dark-gray Mo-Al alloy phase.

The alctivation energy for the infiltration of aluminum into $\mathrm{Mo}_{5} \mathrm{Si}_{3}$ i.s calculated using the Arrhenius equation in the following form (where the reaction rate constant, $K-C L / t$, where $\mathrm{C}$ is the proportionality constant):

$$
\frac{C L}{t}=A \exp \left(\frac{-E_{u}}{R T}\right)
$$

where $A$ is the Arrhenius constant, $L$ the infiltration length, $t$ the inlliltration duration, $T$ the infiltration temperature, and $R$ the universal ges constant. / was maintained at $20 \mathrm{~min}$ in the first set of experiments. The logarithm of infiltration length as a function of inverse temperature is shown in Fig. 5(a). The slope of the plot gives the activation energy $\left(E_{n}\right)$ of the process, which is $\sim 26$ $\mathrm{k} . \mathrm{J} / \mathrm{mol}$. In the next set of experiments, temperature was maintained 

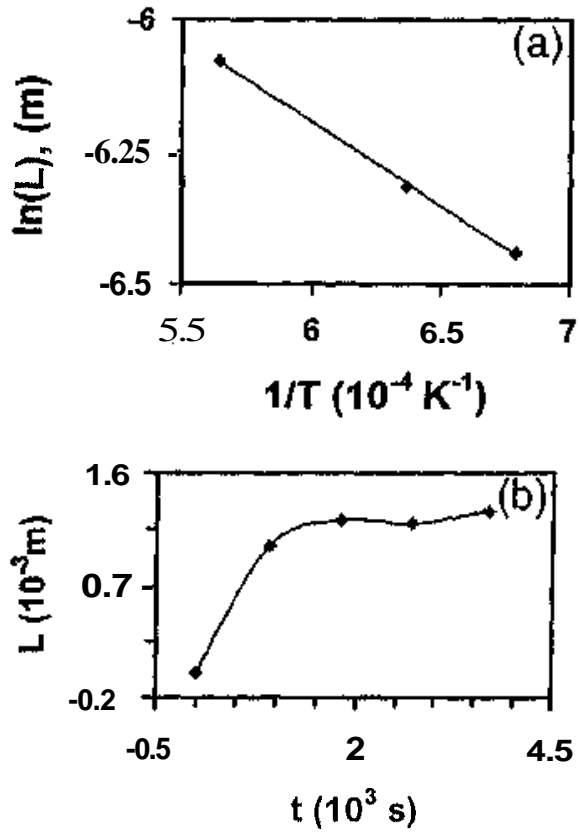

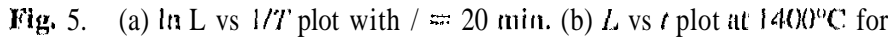
the RMI of aluminum into $\mathrm{Me}_{5} \mathrm{Si}_{3}$ preform.

at 1400$)^{n} \mathrm{Cand}$ the duration of infiltration was varied. The resulting $L$ vs $I$ plol is shown in Fig. 5(b). The length of inl'iltration initially increases and saturates for higher duration.

Although a reaction is taking place, the activation energy is very low for the process of infiltration of aluminum into $\mathrm{Mo}_{5} \mathrm{Si}_{3}$. This means that the infiltration process is mainly governed by the viscous flow of aluminum and that reaction (2) is basically hindering the process. The molybdenum that results after the reaction retards the viscous flow of the aluminum. Hence, the activation energy is $26 \mathrm{~kJ} / \mathrm{mol}$, three times greater than the activation energy for the viscous flow of aluminum $(8.4 \mathrm{~kJ} / \mathrm{mol}))^{8}$ In the $L$ vs $t$ plot, the initial increase in the rate is due to a decrease in the viscosity of aluminum, but after that the increalse in the molybdenum content saturates the infillation process. Therefore, the presence of $\mathrm{Mo}_{5} \mathrm{Si}_{3}$ in the MoSi, preform retards the infiltration process.

\section{Conclusion}

RMI of aluminum into $\mathrm{MoSi}$, -I- Mo and $\mathrm{Mo}_{5} \mathrm{Si}_{3}$ preforms is studied. Irrespective of initial composition, the final product i: always $\mathrm{Mo}\left(\mathrm{Al}_{1}, \mathrm{Si}\right)_{2}$. Infiltration of aluminum into $\mathrm{Mo}_{5} \mathrm{Si}_{3}$ preforn results in the formation of $\mathrm{Mo}(\mathrm{Al}, \mathrm{Si})_{2}$, containing 25-27 al.\% o aluminum, whereas will $\mathrm{MoSi}$, preform only $14-18$ al.\% alumi num reacts. Also, initial composition of the preform affects the ral of inl'iltration. The presence of $\mathrm{Mo}_{5} \mathrm{Si}_{3}$ in the hot-pressed MoSi, -I Mo slows the inl'iltration process, The fower activation energy l'o ihe infiltration process in $\mathrm{Mos}_{5} \mathrm{Si}_{3}$ preform $(-26 \mathrm{~kJ} / \mathrm{mol}$ as com pared with $300 \mathrm{~kJ} / \mathrm{mol}$ for MoSi, preform) indicates thut inlilura tion is governed by the visicoss flow of aluminum.

\section{Relerences}

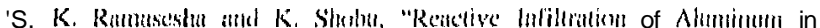

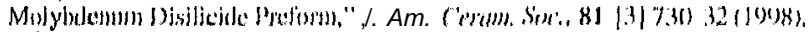

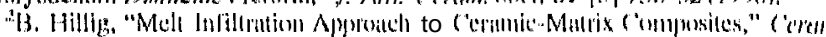

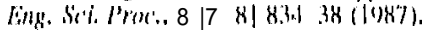

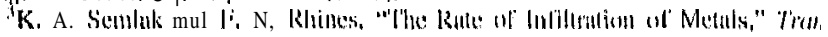
Me'ull. Sint, $A M / h, 212,125 \% 11$ (1058).

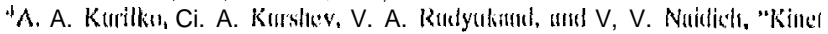

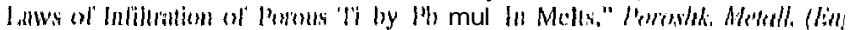
Tronsl, $), 92(1), 3.5,38(10) 8=1)$.

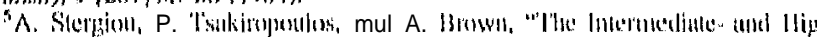

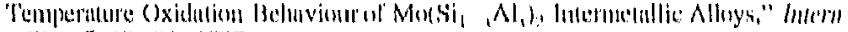
allick, 5, (19)-81 (1007).

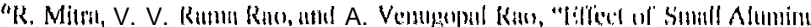

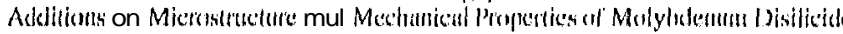
Imermetulliss, 7. 21,3 3\% (1009).

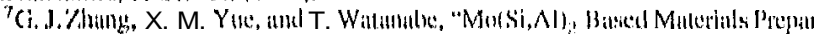

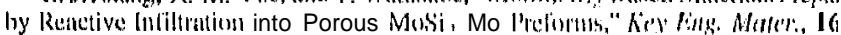
$163,2717<1(\mid(9) 4))$.

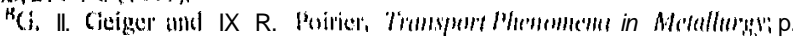
Additionm.Werley, Rending, MA, I9RI). 